\title{
Gravhøjen åbnes
}

\section{Fra rokoko-middelalderisme i Johann Elias Schlegels Canut til vikinge-romantik $i$ Johannes Ewalds Rolf Krage}

I det følgende vil jeg skitsere én gren af middelalderbegejstringens litteraturhistoriske genealogi fra Danmark til Tyskland ved hjælp af Johann Elias Schlegels Canut (1746), på dansk Kong Knud, og Johannes Ewalds Rolf Krage (1770). Disse to tragedier, der henter deres handling fra Saxos Gesta Danorum, er aldrig før blevet sat i forbindelse med hinanden, men minder i handlingen i så høj grad om hinanden, at det er nærved utænkeligt, at Ewald ikke var inspireret af Schlegel. Begge dramaer udgør et opgør med den klassicistiske poetiks stil og stofområde, og forfatterne var i begge tilfælde inspireret af Shakespeare; Ewald desuden af Klopstock og James Macphersons forfalskede gæliske bardedigtsamling Ossians Sange. Ligeledes blev både Kong Knud og Rolf Krage læst og diskuteret af datidens fremmeste tyske og danske digtere og kritikere. Middelalderen står i centrum i den europæiske romantik, og af den grund er det interessant at se, hvordan den gestalter sig på forskellig vis i et drama fra 1746 og et deraf inspireret drama fra 1770. Derfor vil jeg indledningsvis skitsere de to dramaers ensartede handling samt deres digteriske struktur, sproglige udtryksmåde og virkningshistorie for at vurdere, hvordan opfattelsen af middelalderen forandrer sig fra 1746 til 1770 på tværs af dansk og tysk litteratur.

\section{Middelalderlig ære versus oplyst nåde i Kong Knud}

Dramatikeren Johann Elias Schlegel (1719-1749) - med oplysningstidens store tyske dramatiker Lessings ord "det danske teaters tyske digter" - var farbror til de senere berømte Schlegel-brødre i Jena og kom til København i 1743 som elev af klassicisten Johann Christoph Gottsched (1700-1766). Han lærte sig i nogen grad dansk og blev så nær ven med Ludvig Holberg, som man nu kunne blive. Fra april 1745 til april 1746 fik han trykt 52 udgaver af sit eget tidsskrift med titlen Der Fremde. I dette tysksprogede ugeblad skildrede han mødet med dansk kultur (herunder Saxo) set fra en tysk, kosmopolitisk vinkel. På samme tidspunkt arbejdede han - tilskyndet af vennen Hans Grams (1685-1748) aldrig fuldendte oversættelse af Knýtlingasaga - 
på det drama, som han i 1746 udgav under titlen Canut, Ein Trauerspiel. Tragedien skulle være oversat til fransk, hvilket den ikke blev, men til gengæld udkom den i 1747 i en dansk oversættelse ved Jacob Graah (1721-1756) under titlen Kong Knud, Een Tragoedie, Af Tydsk oversat Paa Dansk. Schlegel døde i 1749 i Sorø og blev - som senere Holberg - begravet i Sorø Klosterkirke. Han var en forløber for Københavns tyske kreds, der fra 1750 til 1770 var en litterær avantgarde med den dansk-tyske adelsmand Johann Hartwig Ernst von Bernstorff (1712-1772) i spidsen. ${ }^{2}$ Til Bernstorffs inderkreds hørte den tyske litterære verdensstjerne Friedrich Gottlieb Klopstock (1724-1803), tøndringen Heinrich Wilhelm von Gerstenberg (1737-1823), der i sin litteraturkritik introducerede Herder for nordiske folkeviser, samt den schweiziske historieprofessor Paul-Henri Mallet (1730-1807), hvis oversættelser af norrøn litteratur i Monuments de la mythologie et de la poesie des Celtes, et particulierement des anciens Scandinaves (Mindesmærker om kelters og især skandinavers mytologi og poesi, 1756) fængslede Europas interesse.

Kong Knud er forfattet i klassicismens versemål aleksandriner og henter sit stof fra beskrivelsen af et fejlslagent plot mod Knud den Store (995-1035), der var konge af Danmark, Norge og England i Saxos Gesta Danorum (Danernes bedrifter, fra ca. år 1200). Tragediens handling er kort fortalt: Kong Knuds søster Estrithe ankommer til danskerkongens slot sammen med sin mand, den ærekære svensker Ulf Jarl, der pga. gammelt nag har til hensigt at vælte Knud, rane tronen og vinde ridderæren. En samtale mellem Estrithe og hendes fortrolige Gunilde om Kong Knuds retsind og Ulf Jarls ambition giver et fingerpeg om den kommende konflikt. Estrithe, splittet mellem loyalitet over for ægtemand og broder, opsøges af sin tidligere elskede Godewin og Knud. I et forsøg på at rense Ulf Jarl for mistanke afslører hun uforvarende, at denne har misbrugt en skrivelse fra Knuds hånd til at narre hende til ægteskab med ham i stedet for Godewin. Ulf Jarl indrømmer sin list uden at fortrække en mine: "det var nok værd Umagen” (Schlegel 1747, 25), ${ }^{3}$ siger han lakonisk. En duel mellem Godewin og Ulf Jarl afværges af Knud, hvis modvilje mod "det vilde Mood, som søger Tvedragt [splittelse, AHM]" (s. 31), antager et civilisatorisk præg typisk for det 18. århundrede. Ulf Jarl fortaber sig i længsel efter en forgangen heltetid, "da man glædte sig i Krige" (s. 26). Denne tabte tid stilles i modsætningsforhold til Knud den Stores fredstid, i hvilken "[a]lt Helte-Mood er af Canuti Godhed qvalt" (s. 26). Jarlens monolog udvikler sig til en unaturlig vision om et præagrart krigersamfund: "Den Tiid var Marken, før man lærte den at pløye, / Med Liig besaaed, og Roes var Høsten af den Møye” (s. 26). Ulf Jarls tidligere allierede Godschalck røber over for Knud, at Ulf Jarls hær af angiveligt danskertro soldater, som han just skal til at inspicere, vil myrde ham på dennes ordre. Den ulideligt empatiske Kong Knud udsiger en dødsdom over ham, men martres af sin tunge kongepligt:

46 Af alt hvad Lykken har een fyrste overgivet

Er meest fatal den Ret til Døden og til Livet,

Den tvinger Straffen af, og uretfærdige

Beskylder os, ifald vi er medlidende. (s. 60) 
I en klassicistisk budbringerberetning fortæller Godschalck, hvordan han har dræbt Ulf Jarl i selvforsvar, efter at denne gik løs på ham med draget sværd. Godschalcks drab fritager belejligt kong Knud for dårlig samvittighed; han forbliver således moralsk uanfægtelig tragedien igennem. Stykkets sidste ord udgør hans formaning om, at oplyst, kristen humanisme sejrer over middelalderlig ærekærhed:

Tving dig dog! hvor smerter mig hans Blod!

Hvi blev hand mig utroe med alt sit Helte-mood?

Dog! See! Vor Lyst til Roes og Tragten efter Ære,

Der i og for sig selv berømmelig kand være,

Hvad er den vel, naar vi vor Ære søger i

Vor Næstes Skade? Den er idel Raserie. (s. 61)

\section{Den afskyeligste mand: Ulf Jarl-bølgen i Tyskland og Danmark}

I følgende rids af dens virkningshistorie vil det blive påvist, at Schlegels Kong Knud vakte opsigt både i Danmark og Tyskland og står som én af de første i en lang række af middelalderistiske ${ }^{5}$ tekster forfattet i helstaten Danmark.

Mange har påpeget, at titelfiguren i Schlegels Kong Knud ikke er hovedperson; det er derimod Ulf Jarl. Dens første fortolker, kritikeren Christoph Friedrich Nicolai (1733-1811), viede adskillige sider af sin Abhandlung vom Trauerspiel (Afhandling om sørgespillet, 1757) til Ulf Jarl. "Kan der findes en afskyeligere mand end Ulf Jarl?" (Nicolai 1757, 51), spørger Nicolai, der dog tilkendegiver, at Ulf Jarl besidder karaktertræk, som på sin vis kan siges at være attråværdige eller i det mindste konsekvente, f.eks. hans dødsforagt og krigermoral:

$6 \mathrm{Nu}$ er jeg først tilfreds, jeg det tilsidst nu veed,

At min Død holdes for Canuti Sikkerhed,

Det Sværd, som Fyrster bær, hvormed de Ondskab hemme,

Ey Helte kand, men vel Misædere beskæmme. (Schlegel 1747, 59)

Ulf Jarl frygter ikke døden, for netop i døden vinder han ære derved, at han i live ville udgøre en trussel for kong Knud. Han er til gengæld, mener Nicolai (med rette) en overfladisk karakter. "Helt og aldeles god" (Nicolai 1757, 53) fremstår han uden den tragiske fejl, som Aristoteles foreskriver som nødvendig, hvis handlingen skal vække frygt og medlidenhed. Lessing erklærer sig i et brev til Nicolai enig i denne opfattelse af "en fejl ved Kong Knud": "Helten eller den bedste person må ikke, ligesom en gud, kunne overskue sine dyder som rolige og ukrænkelige" (Lessing 1970, 163).

Også i mere populære genrer vakte Schlegels Kong Knud genklang. I 1771 udkom den celebre romanforfatter Christoph Heinrich Korns (1726-1783) roman Canut der Grosse, oder der Streit der kindlichen und ehelichen Liebe. Eine Heldengeschichte (Knud den Store eller Striden mellem den barnlige og ægteskabelige kærlighed. En heltehistorie). I romanens forord begræder Korn fordommene mod heroiske fortællinger og foreslår, muligvis inspireret af Nicolai og Lessings kritik, at der i fremtiden skrives om mere menneskelige helte. Én tidlig kilde til inspiration for nye helte kom 
fra Sverige, fra "den fra svensk oversatte historie om Adelrik og Gothilde" (Korn 1771), Jacob Henrik Mörks (1715-1763) historiske roman Adelriks och Giöthildas äfwentyr (1742-44). Men romanens skurk, Ulf Jarl, låner Korn "fra det fortræffelige sørgespil Kong Knud af den for tidligt bortgangne hr. Schlegel" (Korn 1771). Korns roman blev anmeldt i Frankfurter Gelehrte Anzeigen af Goethe, der i sarkastiske vendinger karakteriserede dens persongalleri, som "en stiv nation af marionetdukker, rustning, korset og maver udstoppet med gamle klude" (Goethe 1998, 31). Mere mennesketro blev Korns tekst ikke uagtet al ambition derom.

I Nicolais tidsskrift Allgemeine deutsche Bibliothek anså en anonym anmelder i 1772 romanen for at have en handling, der "lod sig reducere til ungefær et kvart hundrede bortførelser, som alle som én forløber på samme vis, ti mark- og søslag og ligeså mange tvekampe og baghold" (Anonym 1772, 581). Anmeldelsen ender med en lammende kritik af spændingsromanens antikverede teatertysk - vi bør bemærke, at det fiktive citat er et aleksandrinervers, anno 1772 indbegrebet af dårlig smag: "For at gøre bogen endnu mere ækel lader forfatteren sine helte tale det usmagelige tragiske sprog, som var på mode for tredive år siden i det tyske teater, i stil med: 'Elsker du mig ej? Godt, så vil jeg dolke mig!'” (s. 583). I 1780 blev historien om Ulf Jarls bedrag atter gendigtet, denne gang af Johann Gabriel Bernhard Büschel (1758-1813) under titlen Canut. Ein Trauerspiel in drey Akten nach Schlegel (Knud. En tragedie i tre akter efter Schlegel) i en prosaudgave, der bedre levede op til Sturm-und-Drang-tidens forkærlighed for naturlig prosa. Værket udkom både som enkeltstående titel og som ét af tre middelalderistiske dramaer i samlebindet Schauspiele für die teutsche Bühne (Skuespil til den tyske scene). I Chronologie des deutschen Theaters, en tidlig tysk litteraturhistorie fra 1775, fremhæves det, at Schlegels Kong Knud "først og fremmest på grund af Ulf Jarls rolle" (Wolf 1964, 173) blev genopført mange gange og nød stor berømmelse i Tyskland.

\section{Kong Knud genoptaget: Troskab og forræderi i Ewalds Rolf Krage}

Ewalds prosadrama Rolf Krage. Et Sørgespil i fem Handlinger fra 1770 bygger på Saxos fortælling om den dydige danske sagnkonge Rolf Krages død efter et komplot mod ham ledt af hans intrigante søster Skulde. Dramaet begynder kort efter en svensk hærs ankomst til Lejre via Isefjorden. Med samme indtog af en søster til kongen, hendes mand og en svensk hær indledes Schlegels Kong Knud. Som kong Knuds søster Estrithe har Rolf Krages søster Skulde indgået ægteskab med en svensk jarl på sin brors opfordring, i dette tilfælde skåningen Hiartvar, der har et horn i siden på Rolf Krage, fordi han som vasalkonge er ham skatskyldig. Skåne siges at være blevet indlemmet i Danmark under Harald Blåtand og var på Saxos tid nærmest at regne for en gammel del af Danmark, men alligevel er Skåne hos Saxo (jf. Mortensen 2018, 4) og Ewald en mindre dansk landsdel end Sjælland.

Også i Ewalds stykke løftes sløret for konflikten indledningsvis af en samtale mellem to kvinder, Rolf Krages gode søster Rude og hendes fortrolige Aluilde. Deres samtale omhandler Rolfs godhed og spørgsmålet om, hvorvidt Hiartvars "Dyd er hærdet nok til at imodstaae Stoltheds Fristelser?” (Ewald 1969, 279). Duelmotivet gentages ligeledes: Rolf forhindrer en duel mellem den tro væbner Hialte og Hiart- 
var og gør tre gange drikoffer til "Freya og de Fredselskende Guder" (s. 291). Både Schlegels Knud og Ewalds Rolf er godtroende og nærer ingen mistanke til svenskerne på trods af fordums nag og nærheden af en svensk hær. Rolf bortforklarer Skulde og Hiartvars bedrag med følgende betragtning:

16 De ere unge begge, og jeg tvivler ikke at de jo liegesaa hastig vil fortryde deres onde Gierning, som de har beslutted den; og hvis ikke .. da overlad Straffen til dem selv .. da ere de straffede nok .. foruden dig .. Men de ere ædle, og overalt .. Helges Børn .. (s. 336)

Skulde skoser sin medsammensvorne Hiartvar for at ville give op, blot fordi Rude har rettet sin mistanke mod dem, og hun blotlægger i en monolog sin magtbrynde: "Staae mig bi Freyer! ... Nei ikke Freyer ... De fredelskende Guder skal flye fra Leyre! ... Haddings Gud, mægtige Vagenhofte! ... Utgaarde Loke! ... Hel! Eller du Frøe, som boer i Upsal!" (s. 296). Disse anråb til de onde guder betoner det unaturlige i hendes væsen. Følgelig bygger hendes lede mod Rolf på foragt for netop hans godhed: "Sin kiereste Søster kaldte han mig, Urses Broder og Søn ... Og saa omfavnede han mig, den Kielne, og tilsoer mit sit Venskab .... Ha! ... hans Venskab ... hørte I ikke hans Gavmildhed?" (s. 301). For Skulde er nåde nemlig lig sindssyge: "Men Rolf kiender ingen Mistanke ... Den afsindige" (s. 301). Der er en parallel mellem Ulf Jarl og Skulde, der ytrer ikke enslydende, men dog i substansens ganske ensartede $\varnothing$ nsker om tilbagevenden til en tidligere ufredstid. En anden parallel ses i deres mindre ambitiøse hjælpere, den underkuede Hiartvar og den vægelsindede Godschalck.

Rolf lægger sig efter et gilde til ro. I løbet af natten går den svenske hær i land, og Rolf konfronteres af den forklædte Hother, som vil hævne sig i tvekamp for Rolfs drab på hans fader Hothbrod. Hother, den splittede helt og stykkets egentlige hovedperson, ender dog med at forsvare Rolf mod Hiartvar, da han ankommer sammen med en gruppe svenskere for at snigmyrde Rolf på æreløs vis. Hiartvar giver Rolf hans banesår. Alle de danske helte myrdes undtagen Viggo, for hvem det ved list lykkes at stikke Hiartvar ihjel: I stedet for et sværge troskab ved et sværd, stikker han Hiartvar med det. Hiartvars mænd kaster sig over Viggo, som udbryder følgende: "Jeg leer af min Død" (Ewald 1969, 377). Han dør således den leende død kendt fra sagaerne (jf. LundgreenNielsen 1969, 11). Hother er værdig til tronen og udråbes til Rolf Krages efterfølger.

Ewalds tragedie har ligesom Schlegels fem akter og overholder tidens og stedets enhed, hvilket Ewald accentuerer i parateksten: "HANDLINGEN begynder ved Solens Nedgang og endes i Dagningen. SKUEPLADSEN er en Skov med nogle Huse i Prospecten af Leyre Slot" (Ewald 1969, 275). Stedets enhed overholdes i teorien, men detaljer på den bemalede scenebaggrund kan oplyses alt efter, på hvilket nærmere sted i nærheden af kongsgården handlingen finder sted, lige så vel som Ewald i fodnoter angiver, når baggrundsstøjen skifter: andre ved større Pragt og ved en Art Illumination, som passer sig på Fæsten og de Tiders Smag. - I Grunden seer man igiennem Træerne en deel af Slottet ligeledes oplyst. Af og til i denne Handling høres Tummel, og forvirrede Frydeskrig. (s. 276) 
I begyndelsen af anden akt angiver regibemærkningerne, at stemningen skifter brat; der er nu tyst og dunkelt, og kun Rolfs hus er oplyst: "Rolfs Lyst-Huus, som ligger oven for Biarkes Huus, og bagerst paa Skuepladsen er illuminered i denne Handling. Paa de øvrige Dele af Skuepladsen er det mørkere, end i den forrige" (s. 296). Ewald kunne øjensynlig ikke forestille sig at bryde med stedets enhed, eller også vovede han det blot ikke, men ved hjælp af en avanceret sceneteknik får publikum fornemmelsen af en eskalerende handling, der bevæger sig fra hus til hus rundt om Lejre slot, ikke ulig svenskernes hærgende indtog. Konventionen om, at vold undgås på scenen og refereres af budbringere, en reminiscens fra den græske tragedie, overholdes af Schlegel, men ingenlunde af Ewald, hvad der også blev bemærket af hans kritikere. Den er erstattet af en indviklet kampkoreografi i form af en myriade af regibemærkninger. Da Hother vil forsvare sig mod Skulde og hendes medsammensvorne i slutningen af tredje akt, giver Ewald i fodnoter nøje anvisninger til, med hvilken gestik og koreograferet kampteknik det skal opføres for publikum:

(f 1 )

1) Hun [Skulde] hugger i Døren, og Hother gaaer imellem den og hende og tager i det samme Skioldet op, som ligger paa Jorden.

2) Hun hugger til ham, men han bøder for sig med sit Skiold.

3) De falde alle ind paa Hother; og Gevar træder paa hans Side for at forsvare ham.

4) Rolf støder Døren op og kommer ud, ubevæbnet. (s. 328)

Derved træder replikkerne i baggrunden, og skuespillet bliver levendegjort af sceneteknik og koreografi. På samme måde forholder det sig med handlingens enhed. Rolf Krage centrerer sig om Rolfs død, men inddrager Hothers historie og andre mindre fortællinger om f.eks. Hialte og Signes kærlighed.

Sproget i Rolf Krage er et kraftfuldt og lyrisk prosadansk med præg af norrønt f.eks. i udråbet "til Agners Minni”' (s. 293) samt 1770'ernes forkærlighed for udråbstegn, afbrudte sætninger og affektudbrud som i Rudes replik til broderen Rolf: "Herre! ... Broder! ... Rolf! ... Han hører mig ikke ... Biarke i det mindste! ... Hialte!” (s. 293). Det er en helt anden form end de schlegelske aleksandrinere og det høje stilleje, som kendetegner samtlige replikker i Kong Knud.

\section{"Bevar os!" Receptionen af Rolf Krage}

I den akademiske granskning er Rolf Krage og Ewalds middelalderisme blevet ignoreret til fordel for unders $\varnothing$ gelser af hans lyriske subjektivisme. ${ }^{7}$ Den umiddelbare reception i Danmark består i Ewalds veldokumenterede problemer med at få publikationsstøtte til tragedien, en kort anonym anmeldelse og en længere af Jacob Baden, der ender med at afvise tragedien ud fra klassicistiske idealer (jf. LundgreenNielsen 1969, 5-6).

Rolf Krage fik også en samtidig reception i Tyskland. Tragedien blev oversat to gange til tysk i 1772 af henholdsvis en vis J. G. Joppert, som Ewald i sit forord til denne oversættelse betegner som danskkyndig tysker og nær ven, og af tyskeren Carl Friedrich Cramer (1752-1807), hvis far Johann Andreas Cramer havde været 
medlem af Bernstorff-inderkredsen og én af Ewalds trofaste støtter blandt Københavns smagsdommere. Goethe forfattede en kort notits om Cramers oversættelse, som udkom i Hamborg, hvorimod Jopperts fik en lang negativ recension af Goethes ven Johann Heinrich Merck (1741-1791) i tidsskriftet Allgemeine deutsche Bibliothek i $1773 .^{8}$

Goethes notits lyder i Brandes' oversættelse, som følger: "Nat, Højforræderi og Brodermord, Blodskam og Død; Mørke, Gru, Elskovs- og Dødskval, saa vi i Tide, med et andægtigt Bevar os! har været betænkte på Hjemrejse" (Brandes 1920, 78). Brandes kalder denne dom "ikke helt retfærdig" (s. 78); Lundgreen-Nielsen istemmer med "ironisk og uden argumenter" (Lundgreen-Nielsen 1969, 7). Det er i alle tilfælde en bevidst ironiserende recensent, der ikke ytrer sig på samme måde som i andre iskolde afvisninger. Kan der spores en kende begejstring bag ironien? Notitsen kan i hvert fald læses som program for Sturm-und-Drang-digtningens tematik.

Ikke én, men to gange anmeldte Goethe en tekst af Ewald i Frankfurter Gelehrte Anzeigen. Han anmelder først, d. 14. juni 1772, Ewalds Der Fall der ersten Menschen. Ein Drama in fünf Handlungen mit Zwischengesängen von Johannes Ewald (1772), en anonym oversættelse af syngespillet Adam og Ewa fra 1769. Denne anmeldelse er anderledes kontant: "At dette afskyelige drama, som vi har foran os, er blevet skrevet, oversat og trykt, dét kan intet menneske tilgive forfatteren, oversætteren og trykkeren" (Goethe 1998, 40). I anmeldelsen nævnes Milton og Dryden som mulige forbilleder - Goethe roser allernådigst Milton for at have ladet tanken om et Adamog-Eva-drama fare. Særlig mener Goethe, at dramaets engle, djævel og mennesker taler "Unsinn" (Goethe 1998, 40), "vrøvl”, og da han ikke giver noget eksempel, og just har nævnt det umulige i en dramatisering af syndefaldet, kunne man få den tanke, at det ikke så meget er replikkerne selv, men selve dét at engle og djævel taler på teaterscenen, som Goethe opponerer mod. Det er interessant, da én af hans kendteste figurer er den særdeles talende djævel Mefistofeles i Faust.

Goethe anmeldte et tredje værk af en Ewald, d. 8.12 i samme år. Dén anmeldelse befatter sig med en udgivelse med titlen Oden von Ewald (Oder af Ewald, trykkeår 1773, men var udkommet i december 1772). Frankfurterudgaven af Goethes værker angiver Johannes Ewald som forfatter til disse oder (jf. Goethe 1998, 1099), men forfatteren må være Schack Hermann Ewald (1745-1822), et randmedlem af de tyske Klopstock-tilbedere kendt som Göttinger Hainbund. Til denne kreds hørte også Ewalds tyske oversætter C. F. Cramer. Udgaven af Schack Hermann Ewalds oder, der indeholder titler som Bardenklage bey dem Tode Friedrich III. Herzogs zu Sachsen 1772 (Bardeklage ved Hertug af Sachsen Friedrich den Tredjes død) og Die Liebe Skiolds und Thorilda (Skjolds og Thorildas kærlighed), angiver hans fulde navn på titelbladet. Det er trods titelbladet tænkeligt, at Goethe, der i sin anmeldelse blot angiver, at det drejer sig om "Oder af Ewald" har associeret denne Ewald med Johannes Ewald, for også Schack Hermann Ewald, "hvem ganske vist barde- og odegrammatikken sådan nogenlunde stod til rådighed, men derimod hverken bardens fantasi, odens følelse eller odens musik" (s. 94), var påvirket af Ossians bardesange og Klopstocks oder.

Merck indleder sin lange anmeldelse i Allgemeine deutsche Bibliothek med en længere genfortælling af Rolf Krage. Han iagttager, at Ewald ligner Shakespeare, der dog er bedre i stand til at puste liv i dramaets personer. Han ser i ægteparret Skulde 
og Hiartvar en genskrivning af Lady Macbeth og hendes mand Macbeth fra Shakespeares drama Macbeth. Derudover gentager han kritikken af den ensidige persontegning idet han deri ser en klar forbindelse til Schlegels Kong Knud: "Den ædle Rolf udstøder enkelte moralske sentenser, som man ikke kan finde mere moderne i den schlegelske Kong Knud" (Merck 1773, 208), en bemærkning, der driver af ironi, for den for længst afdøde Schlegels sprog var alt andet end moderne i 1773. Men Skuldes råb til guderne, citeret i nærværende teksts handlingsreferat af Rolf Krage og udtryk for en anderledes moderne genitidsretorik, falder heller ikke i Mercks smag; hans dom lyder i al sin korthed "höchst lächerlich" (s. 209), "højst latterlig". Forinden bruger Merck ordene "äusserst abentheuerlich[...]", "yderst eventyrlig", (s. 208) om dramaet, hvilket på ingen måde er ment som en ros. Der var i 1770'ernes underholdningslitteratur en overflod af genskrivninger af middelalderens svundne helte; skoleeksemplet er Gottfried August Bürgers folkelige ballader, der nød en enorm popularitet i det årti. Der er i Mercks anmeldelse som i Goethes en dobbelthed. Selvom Merck ikke kan lide det, han har læst, beretter han minutiøst om de gamle nordiske kongers magtspil i sin indledning og ser også i Hiartvars forræderi "die Haupthandlung" (s. 209, "hovedhandlingen") (se også Lundgreen-Nielsen 1969). Merck har faktisk forstået, at dramaet handler om troskab versus forræderi, og han er også ganske godt inde i de danske sagnkongers genealogi samt Ewalds kilder. Rolf Krage gjorde indtryk.

\section{Fredskonger og krigsgale skurke - et middelalderistisk motivs forandring}

Middelalderen er i romantikkens genskrivning i reglen positiv. Det gælder i den tyske Jenaromantik, dansk universalromantik såvel som den senere danske nationalromantik. Når vi, for blot at nævne ét eksempel, synger med på Oehlenschlägers vers om "de harniskklædte kæmper”, skal verset forstås sådan, at vi bør mindes disse fortidens krigere med stolthed. Men denne enkle form for vikingebegejstring er ikke den eneste genskrivning af et motiv fra enten den hedenske vikingetid eller den kristne højmiddelalder, under ét betragtet som én sammenhængende middelalder fra år 500 til år 1500. Også middelalderens dæmoner får nye udtryk i den europæiske litteratur i anden halvdel af 1700-tallet - man kunne som eksempel anføre Goethes "Erlkönig" (1782), den berømteste tyske genskrivning af en dansk folkevise, i hvilken en faders naturvidenskabelige forklaringer på en syg lille drengs dødsvisioner om en truende og forførende elverkonge er ingen nytte til. Middelalderen bliver et mangefaceteret spejl, som romantikerne kan spejle deres angst og længsler i.

Schlegel er en tidlig middelalderist. Ganske vist havde hans lærermester Gottsched interesseret sig for tysk litteratur- og sproghistorie, herunder det nedertyske epos Reynke de vos, som han oversatte til moderne højtysk og udgav i en kritisk udgave i 1752 under titlen Reineke Fuchs (En Ræffue Bog, dvs. Rævebogen, oversat til dansk allerede i 1555), men det var et novum i tysk dramatik, at Schlegel efter at have skrevet klassicistiske skuespil med titler som Orest og Pylades eller Dido i 1743 kunne udgive sin Hermann, historien om germanerhøvdingen Hermann som de romerske historikere kaldte Arminius - længe inden bølgen af Hermann-dra- 
maer, som tog sin begyndelse med Klopstocks Hermannsslaget (1769). Som én af de første middelalderistiske forfattere måtte han ty til latinske kilder, for Schlegel skriver inden den nordiske renæssance (Blanck 1912), altså bølgen af middelaldergendigtninger med afsæt i den tyske kreds i København og Sorø. Det er sigende for denne tidlige middelalderisme, at Schlegel kender de islandske sagaer fra latinske oversættelser. Norrønt kunne så godt som ingen i Tyskland i midten af 1700-tallet - undtagelsen er Gerstenberg, der i sin litteraturkritik fremhæver, at han oversætter fra originalens oldislandske til tysk (jf. Gerstenberg 1890, 238). Forlægget for Mallets eddaoversættelse var Peder Hansen Resens (ofte latinificeret til Resenius) Edda Islandorum (1665), en udgave med oldislandsk, dansk og latinsk paralleltekst. Schlegels udgangspunkt er derfor Saxos avancerede latin med påvirkning fra den romerske sølvalderlitteraturs retoriske stil, hvorimod Ewalds udgangspunkt var Anders Sørensen Vedels danske Saxo-oversættelse fra 1575. Med tanke på stykkets klassicistiske opbygning, versenes aleksandrinerform og den patosladede karaktertegning typisk for den sene oplysningstid kan stykkets fremstilling af den danske fortid betegnes som rokoko-middelalderisme.

Af disse grunde er Kong Knud væsensforskellig fra de højromantiske riddertidsfortællinger efter år 1800. Middelalderens æresbegreber står entydigt i et modsætningsforhold til datidens idealstat. Stykkets helte, Knud og Estrithe, er 1700-talsmennesker placeret i en middelalder, der med en kliché kan betegnes som mørk. Den nådige og i alle henseender perfekte kong Knud er et billede på, hvordan en konge skal opføre sig anno 1746. Schlegel var i 1740'erne Frederik den Femtes hofdigter, og det var en opførsel af hans prolog Die Langeweile (Kedsomheden), som Det Kongelige Teater fejrede sin genåbning med i 1747. Årsagen til Schlegels interesse for nordisk middelalder var hans teori om, at en nation har brug for en national scene, på hvilken der opføres teaterstykker, der passer til publikums særegne nationale identitet, her udtrykt i skriftet Gedanken zur Aufnahme des dänischen Theaters (1747, først trykt i 1764, Tanker om det danske teaters udbredelse): "For hver nation fastsætter for sit teater, hvis den skal finde behag derved, også forskellige regler på grundlag af forskellige skikke, og et stykke, som er skabt for én nation, vil sjældent for alvor behage de andre" (Schlegel 2009, 76).

Det hører med til en karakteristik af Schlegels 1700-tals-nationalisme, at den ingenlunde er en hårdtoptegnet afgrænsning af den nationale mythos, men snarere en kosmopolitisk nationalitetsdyrkelse, inden for hvilken "det ville være en stor fornøjelse for forstanden at indse forskelligartetheden i alle nationers karakterer ud fra fremmede skikkes forestillingsverden" (s. 101). Men hans teaterreform-idéer gav sig ikke kun udslag i en opblødning af klassicismens regelværk. Også karaktertegningen afviger drastisk. I antikken var den tragiske helts modstander i udgangspunktet ikke en klassisk skurk, men Nødvendigheden, de højere magter. Anderledes er det hos Shakespeare, som Schlegel allerede havde bekendt sig til i en afhandling fra 1741 - én generation før Sturm-und-Drang-generationens Shakespeare-fascination og Wielands berømte oversættelse. Kong Macbeth blegner hos Shakespeare i forhold til Lady Macbeth. Hvis man er på udkig efter onde personer hentet fra en germansk fortid, er der intet bedre sted at lede end hos Saxo, hvis skildring af Ulf Jarls laster ikke lader noget tilbage: Saxo begrunder i tiende bog af sin Danmarks- 
krønike Ulf Jarls ondskab i hans oprindelse som efterkommer af en monstrøs bjørn og dennes voldtægtsoffer. Modsat den græske tragedies helte, der ifølge Aristoteles kun skulle besidde én tragisk fejl (hamartia), er romersk historiografi, én af Saxos inspirationskilder, centreret om det moralske exemplum, mønstereksemplet på et dydigt eller utugtigt menneske. En anden romersk tekst, som man ved påvirkede Saxo, er Vergils stoicistiske epos Æneiden.

Danmarks fortid får på baggrund af de mange nye kilder til fortiden og tidens nye stormfulde poetik en anden udformning hos Ewald end hos Schlegel. Fra 1746 til Ewalds forsøg på at slå igennem som dramatiker i 1770 var der sket mangt og meget: Bernstorff havde i 1750 påbegyndt sin storstilede kulturimport, og med Struensees magtovertagelse i 1770 var hans æra forbi. Men den havde sat sig spor. Middelalderen var i 1770 på nippet til at gå fra at være en periode, som man primært interesserede sig for akademisk til at erstatte antikken som arnested for nye litterære former og motiver. Den blev en afrundet verden, der i sig selv både indeholdt gode og onde karakterer. Hos Ewald er Rolf måske nok "anakronistisk from" (Lundgreen-Nielsen 1969, 11), men han besidder samtidig kvaliteter, som i et oldnordisk vikingeunivers var positive, og som ikke kongruerer med kongeidealet på Ewalds tid; f.eks. kan han bande på en slags oldnordisk: "Til Ragnarokr være den forbandet!" (Ewald 1969, 291). I det ewaldske middelalderunivers er volden ikke på samme måde tabu. Et yderligere eksempel er, at handlingen er inspireret af den hedenske del af Saxos Gesta Danorum og derfor henlagt i et asatro miljø uden noget fors $\varnothing \mathrm{g}$ fra Ewalds side på at nedtone den gamle nordiske tro. Tværtimod accentuerer han det norrøne element, når han kan, og giver i et appendiks ordforklaringer af ord som "Valkyrier", "Loke i Utgaard" og "Minni”. Det er også muligt for Ewald, måske netop fordi handlingen foregår i sagnkongetiden, at lade en god dansk konges død finde sted på scenen. Den tvivlende Hothers tanker om ære versus tilgivelse nuancerer Schlegels skarpe grænse mellem godt og ondt, fordi Hother, om end han ikke havde lyst, valgte hævnens vej og udfordrede Rolf til en tvekamp, som dog blev forpurret af svenskernes feje snigmord. Hother overvejer hævnens natur: "gavmilde, fromme, dydige Rolf! .. og at Hævngierrighed ... Grusomme Nødvendighed! .. naar blev du Dyd?” (Ewald 1969, 318). En senere monolog (s. 318-319) afslører, at den kommende Lejrekonge Hother har et særdeles konfliktfyldt indre, som sammenlignet med den schlegelske kong Knuds moralske befippelse over at skulle dødsdømme Ulf Jarl virker ægtefølt og gør idealkongen til følelsesmenneske snarere end fjern rationalist. I Kong Knud er kongens splittelse mellem humanisme og magt aldrig for alvor hovedtemaet (jf. Schütz 1980, 112), men i portrættet af Hother griber Ewald tvivlen og gør den til et troværdigt karaktertræk.

Det rebelske sprog er et produkt af Shakespeares blankvers, påvirkningen fra norrønt og Klopstocks frie lyriske vers og stemmer godt overens med Vedels oversættelse, der ikke besidder Saxos imiterede sølvalderlatins forkunstlethed. Vedel giver en prosaoversættelse af Bjarkemål og andre norrøne skjaldesange, som Saxo i en imitation af skjaldesangens kompleksitet overførte til den romerske poesis mest kunstfærdige vers. Middelalderbilledet var med andre ord i skred i midten af 1700-tallet, ikke mindst i opfattelsen af, hvordan en litterær form, som var formet af noget andet end antikkens idealer, kunne se ud. 


\section{Romantiske udvekslinger mellem Danmark og Tyskland omkring år 1770}

Det middelalderspor, som Kong Knud indleder og Rolf Krage genoptager, tematiserer troskab over for forræderi i den enkeltes møde med staten. De to teaterstykker giver hver deres bud på, hvordan man som kongetro bør agere stillet over for et grænseløst menneske. Patriotismen forstået som stiliseringen af et væbnerideal fra middelalderen bliver - overført til 1700-tallets oplyste enevælde - til et borgerideal. Klart er dog, at hvor Knud og Rolf er kedelige nådekonger, er Ulf Jarl og Skulde samt Hother, som man et stykke hen ad vejen betragter som skurk, og de medsammensvorne hofsnoge Godschalck og Hiartvar langt mere interessante i henholdsvis deres magtsyge, vægelsind og følgagtighed. Det moralsk anfægtelige menneske træder her ind på den europæiske scene, hjulpet af Shakespeare og Saxo og den hele middelalderlitteraturs skildring af de nordiske helte og deres modpoler. Man kan næsten fristes til at holde med skurkene, fordi kongernes omfavnende empati virker kvælende.

Denne modpol udvikler sig i videre historicistisk litteratur og genfindes i ny gestaltning i Karl Moor i Schillers Røverne (1781) eller i Michael Kohlhaas fra Heinrich von Kleists drama af samme navn fra 1808 (jf. Schütz 1980, 111). I begge tilfælde er persontegningens entydighed erstattet af et subtilt portræt af et tvivlende menneske, der ikke uden grund står i opposition til staten, men som alligevel ender i en spiral af grænseløs vold.

Goethes gennembrud, ridderdramaet Götz von Berlichingen mit der eisernen Hand. Ein Schauspiel (1773) - berømmet for sin antiklassicistiske opbygning og sit djærve frisprog - er forfattet efter diskussioner med Herder netop i årene 1771 til 1773, hvor Ewald ud over at opnå anmeldelser af Goethe og Merck også blev nævnt og citeret i Gerstenbergs virkningsfulde litteraturbreve: I nittende brev af Briefe über die Merkwürdigkeiten der Litteratur (1766-1770), også kendt som Schleswiger Literaturbriefe (Breve om litteraturens mærkværdigheder), nævnes ud over Jens Schielderup Sneedorfs prosatekst Den nye Edda eller Gylfes anden Reise (1764), Alexander Pope, Edward Young og et væld af andre også Johannes Ewalds digt Lykkens Tempel. En Drøm (1764) Ydermere citerer Gerstenberg i det trettende brev Ewalds Kantate i Roeskilde Dom-Kirke den 19de Martius 1766 da Kong Frederik den Femte blev samlet med sine Fædre, dog uden at nævne Ewalds navn. Her har Herder i brødteksten kunnet læse følgende vers; Gerstenbergs tyske oversættelse var henvist til en fodnote:

Jeg seer de majestätisk tause Huuler, Jeg seer de stolte Boliger, som skiuler Monarkers Been.

Jeg øyner alt det Sted Hvor Nordens Fryd skal graves ned En Lyd af Suk blev hørt i Tausheds Bolig Hvad Grad tør vel forstyrre dette Sted Hvor Nordens Helte hvile sig i Fred? (Gerstenberg 1890, 104; se også Jørgensen 1888, 72) 
Det er altså klart, at "Nordens Helte" for Gerstenbergs læsere må være forbundet med Danmark. I 1814 kunne Goethe i tolvte bog af sin selvbiografi Digtning og Virkelighed indgående beskrive det nordiskes indtog i tysk litteratur i tiden omkring 1770; som eksempler nævner han de nordiske guders navne populariseret i Klopstocks oder samt sin egen læsning af "Indledningen til Mallets 'Danmarks Historie"' samt "Resenius's 'Edda Islandorum"' (Goethe 1928, 166), som han havde fået af Herder. Ét element af den nordiske renæssance bestod i "en Aand, som hævder, at al Styrelse, den være sig monarkisk eller aristokratisk, bør afskaffes” (s. 165), velsagtens en henvisning til forestillingen om menneskets før-civilisatoriske, oprindelige frihedstilstand. Op imod dén anarkistiske ånd skrev Goethe sin Götz, påstår han, i en lang muligvis revisionistisk bemærkning, der ikke desto mindre viser, at Goethes Götz blev til i et livtag med datidens middelalderistiske litteratur:

4 Skut

Skulde jeg muligvis være blevet smittet af den omtalte Sot, saa søgte jeg kort Tid efter at digte mig fri for den i ‘Götz von Berlichingen', hvor jeg har fremstillet en ædelttænkende, retsindig Mand, som i en lovløs Tid paatager sig det Ansvar at stille sig i Lovens og den udøvende Magts Sted, men fortvivler, da han mærker sig mistænkt, ja betragtet som en frafalden af sin Kejser, hvis Overhøjhed han loyalt anerkender. (s. 166)

Også Goethes Götz-figur er et moralsk menneske, hvis kardinaldyd er troskab. Goethe var inspireret af Schlegels Hermann, som i 1766 var blevet opført til åbningen af et nyt teater i Leipzig. Han fandt dog, at Schlegel gik for langt tilbage i middelalderen (jf. Goethe 2000, bd. 4, 487). Som barn havde han i øvrigt i rollen som Knud opført Kong Knud sammen med sin søster, der selvfølgelig spillede Estrithe (jf. Goethe 2000, bd. 9, 158); Ulf Jarl blev spillet af en søn af patricieren Johann Daniel von Olenschlager, i hvis hus børnene opførte deres teaterstykker. Også Goethes hovedperson, den historiske figur Gottfried von Berlichingen zu Hornberg (cirka 1480-1562), står i opposition til kejsermagten, og hele dramaet kredser om troskab over for forræderi og det geniale menneskes forhold til den verden, som begrænser ham. Goethe genoptager det spor, som Schlegel og Ewald havde populariseret, dog blev Götz i sin Urfassung nedskrevet før Goethes anmeldelse af Ewalds drama, men omarbejdet i tiden indtil 1773.

Noget de fleste litteraturhistoriske fremstillinger er enige om, er, at dansk romantik i sin grundvold er tysk, og at det skyldes påvirkningen fra Jena i den strømning, der har fået prædikatet universalromantik. Men den tyske præromantik og romantik hviler, som vi har set, bl.a. på dramaturgiske landvindinger foretaget først med spæde spadestik af Johann Elias Schlegel og senere genoptaget og gjort mere vidtrækkende af Johannes Ewald. 'Middelalderlig' eller 'ridderlig' var netop den oprindelige betydning af ordet 'romantisk' hos Jena-romantikerne. Fascinationen af det middelalderlige er selve romantikkens vigtigste kendetegn. Hvad gestaltningen af middelalderen angår, var dansk litteratur i tiden fra 1746 frem til 1770 milevidt forude for den tyske litteratur, der indtil Sturm-und-Drangperioden standede i våde og dårligt havde blik for andet end romersk og fransk litteratur. Der går en lige linje fra Kong Knud over Rolf Krage til 1770'ernes besættelse af det stærke geni og dets kamp med den omverden, der ikke forstår det, samt 
den senere romantiks yndlings-setting, middelalderen og opblødningen af det aristoteliske regelværk. For dansk litteraturs vedkommende fik Rolf Krage afgørende betydning for Oehlenschläger. For også hans livtag med nordens helteverden indledtes med Ewalds Rolf Krage: "I Ewalds Rolf Krage aabnede den nordiske Saga førstegang sine Gravhøie for mig, viste mig sine Askekrukker og fremmanede sine Aander" (Oehlenschläger 1850, 32).

\section{Noter}

I Citatet stammer fra Lessings indledning til Hamburgische Dramaturgie (Lessing 1958, 3) og er oversat af mig selv. Med mindre andet er angivet, har jeg i nærværende artikel selv oversat fra tysk til dansk.

2 Der findes tre standardfremstillinger af Bernstorff-kredsen, alle af ældre dato: En amerikansk (Eaton), en svensk (Blanck) og en tysk (Magon). En nyere, kortfattet beskrivelse af Bernstorffkredsen og dens virkning ses i Povlsen (2007) eller Sørensens afsnit "Ewald og Klopstock - det tyske miljø i København" (Sørensen 1997, 35-36).

3 Her og i det følgende citereret på dansk efter Jacob Graahs mindre vellykkede piratoversættelse fra 1747 (Schlegel 1747). Schlegels broder Johann Heinrich Schlegel, der udgav hans værker, gjorde opmærksom på oversættelsens manglende kvaliteter (jf. Schlegel 1971, 214). Originalen er skrevet på et smukt, høvisk tysk.

4 Oversættelsens "Canuti" er en latinsk genitiv. Af metriske hensyn bruger Graah modsat forlægget latiniserede former af Knuds navn, hvad der ikke gør hans oversættelse mere flydende.

5 Middelalderisme er et begreb, der dækker senere epokers genskrivninger af middelaldermotiver. For en længere redegørelse for middelalderismeforskningen henvises til Kjærulf 2018.

6 Minni er oldnordisk for 'minde', 'erindring'.

7 Jf. Lundgreen-Nielsen 1969, 5. Heller ikke nyere Ewald-forskning levner Rolf Krage megen opmærksomhed. Kau giver en ideologikritisk læsning af Hother som hovedperson i en hævdelse af enevælden (Kau 1977, 91-94), Zeruneith omtaler Hother som en perspektiverende figur til Balder fra Ewalds Balders Død (Zeruneith 1985, 290-292), og Sørensen beskæftiger sig kun kortfattet med Ewald som dramatiker og kun med Balders Død og Fiskerne (Sørensen 1997, 139-146).

8 Der hersker i sekundærlitteraturen forvirring om disse to oversættelser. Lundgreen-Nielsen skriver, at Merck anmelder den anonyme oversættelse, hvormed han mener Cramers, men rent faktisk anmelder han med sikkerhed Jopperts (Merck 1773, 210). Lundgreen-Nielsen skriver desuden, at Goethe skrev om Jopperts version, men det passer ikke med oversættelsens trykkested Hamborg i Goethes korte notits (Goethe 1998, 87). Goethe anmeldte Cramers oversættelse, der udkom netop i Hamborg uden angivelse af oversætterens navn (Ewald 1772b). Oversætterens forord er tydeligvis forfattet af en tysker, der ikke står i umiddelbar nær forbindelse med Ewald, som han dog mener at vide, er syg. Han skriver: "Johannes Ewald lever endnu, og, så vidt jeg ved, dét enten i København eller tæt derved" (Ewald 1772b, VI). I forordet betones Ewalds geni samt det tyske behov for nordisk mytologi og historie som emner i litteraturen. Oversætteren er bekendt med Bernstorffs fald i 1770 (Ewald 1772b, VII). Endelig angiver han, at skriftet ikke blev støttet af Selskabet til de Skiønne og nyttige Videnskabers Forfremmelse (Ewald 1772b, VIII). Cramers fader var dengang medlem af bedømmelsesudvalget og én af de få positive læsere af tragedien (Eaton 1929, 135). Faderen var en stålsat Bernstorff-tlhænger og 
flyttede i 1771 efter Bernstorffs fald fra København til Lübeck (Eaton 1929, 136). Den unge Carl Friedrich Cramer har med oversættelsen formentlig ønsket af redde ét af Bernstorff-kredsens digterværker fra glemslen. Dét må Ewald have hørt om, for han skriver i forordet til Jopperts oversættelse følgende: "Man har - hvordan skal jeg formulere det - truet eller smigret mig med forlydender om en tysk oversættelse" (Ewald 1772a). Ewald frygtede med rette en elendig oversættelse (Krähe, 32). Senere skulle den unge Cramer oversætte en række andre tekster af Ewald samt af andre danske forfattere, herunder Ewalds Fiskerne og Jens Baggesens Labyrinten samt hans opera Holger Danske. Om hans virke som 'grænsegænger' se Jørgensen 2001.

\section{Litteratur}

Anonym (1772): “Canut der Große, oder der Streit der kindlichen und ehelichen Liebe”, i Allgemeine deutsche Bibliothek. Des neunzehnten Bandes zweites Stück, Berlin und Stettin: Verlegts Friedrich Nicolai, s. 581-583.

Blanck, Anton (1911): Den nordiska renæssansen i sjuttonhundratalets litteratur. En undersökning av den 'götiska' poesiens allmänna och inhemska förutsättningar, Stockholm: Albert Bonniers Förlag. Brandes, Georg (1920): Wolfgang Goethe, København: Gyldendal.

Eaton, J. W. (1929): The German Influence in Danish Literature. The German Circle in Copenhagen 1750-1770, Cambridge: Cambridge University Press.

Ewald, Johannes (1772a): Rolf Krage. Ein Trauer-Spiel in fünf Handlungen von Johannes Ewald. Aus dem Dänischen übersetzt von Joppert, Københagen og Leipzig: Bey Rothens Erben und Prost.

Ewald, Johannes (1772b): Rolf Krage ein Trauerspiel in fünf Handlungen von Johannes Ewald. Aus dem Dänischen übersetzt, Hamburg: Bey Bode.

Ewald, Johannes (1782): Samlede Skrifter. Andet Bind. Med Kobbere, København: Christian Gottlob Prost.

Ewald, Johannes (1969): Johannes Ewalds samlede skrifter. Første bind, København: Gyldendal. Ewald, Schack Hermann (1773): Oden von Schack Hermann Ewald, Gotha: Carl Wilhelm Ettinger. Gerstenberg, Heinrich Wilhelm (1890): Briefe über die Merkwürdigkeiten der Litteratur, Stuttgart: G. J. Goschen'sche Verlagsbuchhandlung. Hentet d. 31. Januar 2019 fra: http://www.zeno.org/ Literatur/M/Gerstenberg, +Heinrich + Wilhelm + von/Theoretische+Schrift/Briefe +\%C3\%BCber + Merkw\%C3\%BCrdigkeiten+der+Literatur.

Goethe, Johann Wolfgang von (1998): Sämtliche Werke. Briefe, Tagebücher und Gespräche. I. Abteilung: Sämtliche Werke Band 18. Ästhetische Schriften 1771-1805, Frankfurt am Main: Deutscher Klassiker Verlag.

Goethe, Johann Wolfgang von (2000): Werke. Hamburger Ausgabe, Hamburg: Deutscher Taschenbuch Verlag.

Goethe, Johann Wolfgang von (1928): Goethes Værker ved P.A. Rosenberg. XIV. Digtning og Virkelighed. II, Købenavn: H. Aschehoug og Co. Dansk Forlag.

Jørgensen, A.D. (1888): Johannes Evald, København: Gyldendal.

Jørgensen, Sven-Aage (2001): “Carl Friedrich Cramer: Ein verunglückter Nachzügler der Gesammtstaatskultur" i Detering, Heinrich, Anne-Bitt Gerecke og Johan de Mylius (red.): Dänisch-deutsche Doppelgänger. Transnationale und bikulturelle Literatur zwischen Barock und Moderne (Grenzgänge. Studien zur skandinavisch-deutschen Literaturgeschichte. Bd. 3), Göttingen: Wallstein Verlag. 
Kjærulf, Berit (2018): "Medievalism and the post-medieval Middle Ages. A review of Anglophone medievalism studies", i Orbis Litterarum 73.5, s. 458-470.

Korn, Christoph Heinrich (1771): Canut der Grosse, oder der Streit der kindlichen und ehelichen Liebe. Eine Heldengeschichte, Ulm: Albrecht Friedrich Bartholomäi.

Krähe, Ludwig (1907): Carl Friedrich Cramer bis zu seiner Amtsenthebung (Palaestra XLIV. Untersuchungen und Texte aus der deutschen und englischen Philologie), Berlin: Mayer \& Müller.

Lessing, Gotthold Ephraim (1970): Werke. Band 4, München: Hanser Verlag.

Lessing, Gotthold Ephraim (1958): Hamburgische Dramaturgie. Kritisch durchgesehene Gesamtausgabe mit Einleitung und Kommentar von Otto Mann, Stuttgart: Alfred Kröner Verlag.

Lundgreen-Nielsen, Flemming (1969): "Mulm og skræk og kamp og død. Johs. Ewalds 'Rolf Krage”, i Danske Studier, s. 5-19.

Lundgreen-Nielsen, Flemming (2017): “Grundtvigs vej til Saxo", i Grundtvig-Studier 66.1, s. 55-102. Hentet d. 31. januar fra: https://tidsskrift.dk/grs/article/view/26336

Magon, Leopold (1926): Ein Jahrhundert geistiger und literarischer Beziehungen zwischen Deutschland und Skandinavien 1750-1850. Erster Band: Die Klopstockzeit in Dänemark. Johannes Ewald, Dortmund: Fr. Wilh. Ruhfus.

Merck, Johann Heinrich (1773): "Rolf Krage. Ein Trauerspiel in fünf Handlungen, von Joh. Ewald", i Allgemeine Deutsche Bibliothek. Des zwanzigsten Bandes erstes Stück, Berlin og Stettin: Verlegts Friedrich Nicolai, s. 207-210.

Mortensen, Lars Boje (2018): Saxo (100 danmarkshistorier), Aarhus: Aarhus Universitetsforlag.

Müller-Wille, Klaus (2016): "Romantik - Biedermeier - Poetischer Realismus (1800-1870)”, i Skandinavische Literaturgeschichte, Stuttgart: J. B. Metzler Verlag, s. 133-185.

Nicolai, Friedrich (1757): "Abhandlung vom Trauerspiele", i Bibliothek der schönen Wissenschaften und freyen Künste. 1. Stück, Leipzig: Dyck, s. 17-68. http://brawe.uni-leipzig.de/docuverse/1757_nicolai_abhandlung_vom_trauerspiele.html, tilgået d. 21. januar 2018.

Oehlenschläger, Adam (1850): Oehlenschlägers Erindringer. Første Bind, København: Andr. Fred. Høsts Forlag.

Povlsen, Karen Klitgaard (2007): “Travelling Mythologies of the North around 1760. Molesworth, Mallet, Gerstenberg and several others in Copenhagen”, i Karen Klitgaard Povlsen (red.): Northbound. Travels, Encounters and Constructions 1700-1830, Aarhus: Aarhus Universitetsforlag.

Schlegel, Johann Elias (2009): Canut. Ein Trauerspiel, Stuttgart: Reclam.

Schlegel, Johann Elias (1747): Kong Knud, Een Tragoedie, Af Tydsk oversat paa Dansk, København: Frantz Christian Mumme.

Schlegel, Johann Elias (1971): Werke. Herausgegeben von Johann Heinrich Schlegel. Band I, Frankfurt am Main: Athenäum.

Schütz, Sigrit (1980): "Der übertrieben positive Nationalheld. Zum Problem des fehlenden tragischen Konflikts in Johann Elias Schlegels Trauerspiel Canut", i Lessing Yearbook 12, s. 107-122.

Sørensen, Peer E. (1997): Johannes Ewalds digtning og poetik (Hesperides. Studies in Western Literature and Civilization), Trieste: Edizioni Parnaso.

Wolf, Peter (1964): Die Dramen Johann Elias Schlegels. Ein Beitrag zur Geschichte des Dramas im 18. Jahrhundert (Zürcher Beiträge zur deutschen Literatur- und Geistesgeschichte 22), Zürich: Atlantis Verlag.

Zeruneith, Keld (1985): Soldigteren. En biografi om Johannes Ewald, København: Gyldendal. 